\title{
Evaluation of Etiological Risk Factors in the Development of Adult Chronic Pilonidal Disease
}

\section{Erişkin Kronik Pilonidal Sinüs Hastalığının Oluşumunda Etiyolojik Risk Faktörlerinin Değerlendirilmesi}

\author{
(1) Adnan Kuvvetli, @ (1) Süleyman Çetinkunar, @ Alper Parlakgümüş \\ University of Health Sciences, Adana City Training and Research Hospital, Clinic of General Surgery, Adana, Turkey
}

\section{HIIIII| ABSTRACT}

Aim: Pilonidal disease has a high rate of recurrence after surgical interventions and measures that can be taken to prevent the recurrence are gaining importance. This study was planned to review the possible risk factors and to provide guidance for the reduction of pilonidal disease.

Method: Patients diagnosed with pilonidal disease between January 2014 and January 2017 were evaluated. Age, gender, weight, height, body mass index (BMI), occupation and sitting or standing position during working, family history of pilonidal sinus, skin color and hair color were analyzed retrospectively. The BMI of the patients was categorized as $\leq 20.0 \mathrm{~kg} / \mathrm{m}^{2}, 20.1-25.0 \mathrm{~kg} / \mathrm{m}^{2}, 25.1-30.0 \mathrm{~kg} / \mathrm{m}^{2}, 30.1-35.0 \mathrm{~kg} / \mathrm{m}^{2}$ and $35.1-40.0 \mathrm{akg} / \mathrm{m}^{2}$.

Results: The total number of patients with pilonidal disease was 217 with a mean age 26.0. The disease had two age peaks at 19 and $24-27$ years. Pilonidal disease was statistically significantly more commonly observed in patients with BMI of $25.1-30.0 \mathrm{~kg} / \mathrm{m}^{2}(\mathrm{p}<0.001$ ). The disease was significantly higher in brunette patients compared to auburn and blonde patients $(\mathrm{p}<0.001)$. The disease was observed in $49.8 \%$ patients with seated positional occupations $(\mathrm{p}<0.001)$.

Conclusion: Age, skin color and hair color are unmodifiable risk factors, but prevention of obesity, reducing sitting time and changing routines while fulfilling occupations seem preventive methods.

Keywords: Etiology, pilonidal sinus, prevention

\section{|||||||||| ÖZ}

Amaç: Pilonidal sinüs hastalığı cerrahisi sonrası yüksek oranda oluşan nüksler nedeniyle hastalık oluşmaması için alınabilecek önlemler önem kazanmaktadır. Bu çalışma olası risk faktörlerinin gözden geçirilip pilonidal hastalığın önlem alınarak azaltılmasında ışık tutması amacıyla planlanmıştır.

Yöntem: Ocak 2014 ve Ocak 2017 arası pilonidal sinüs tanısı almış hastalar değerlendirildi. Yaş, cinsiyet, ağırlık, boy, vücut kitle indeksi (VKì), iş ve oturur veya ayakta icra edilişi, ailede pilonidal sinüs varlı̆̆ , deri ve saç rengi, retrospektif olarak analiz edildi. Hastaların VKI’si $\leq 20,0$ kg/m² , 20,1-25,0 $\mathrm{kg} / \mathrm{m}^{2}, 25,1-30,0 \mathrm{~kg} / \mathrm{m}^{2}, 30,1-35,0 \mathrm{~kg} / \mathrm{m}^{2}$ and $35,1-40,0 \mathrm{~kg} / \mathrm{m}^{2}$ olarak kategorize edildi.

Bulgular: Pilonidal sinüs olan 217 hastanın ortalama yaşı 26,0 idi. On dokuz ve 24-27 yaş aralığı, hastalarda 2 ayrı pik yapmış olarak görüldü. Pilonidal sinüs VKİ'si $25,1-30,0 \mathrm{~kg} / \mathrm{m}^{2}$ olan hastalarda istatiksel olarak sık görüldü ( $\mathrm{p}<0,001$ ). Esmer tenli hastalarda, sarışın ve kumrallara göre istatistiksel olarak bu hastalık daha sık idi $(\mathrm{p}<0,001)$. Oturarak icra edilen mesleklerde bu hastalığın görülme oranı \%49,8 idi ( $<<0,001$ ).

Sonuç: Hastanın yaşı, ten ve saç rengi değiştirilebilir risk faktörü değildir ancak obezitenin engellenmesi, oturur pozisyonda yapılan işlerde mümkünse sürenin kısaltılması veya icra ederken iş alışkanlığının değiştirilmesi preventif olabilir görülmektedir.

Anahtar Kelimeler: Etiyoloji, pilonidal sinüs, önlem 


\section{Introduction}

Pilonidal sinus (PS) is a common surgical disease with a midline or lateral hair-containing sinus in the natal cleft. ${ }^{1}$ Although the etiology is not known exactly, risk factors include increased hair amount in the region, male gender, obesity, prolonged sitting, family history, trauma, irritation of the coccyx, and inattention to personal hygiene. ${ }^{2}$ The incidence shows variability due to geographical- and population-based conditions. ${ }^{3,4}$ Because of the high rates of recurrence after surgical interventions, prevention is preferred to therapy. Therefore, here we performed this study to determine the factors associated with an increased risk of PS that could be avoided, and to provide guidance for the reduction of PS.

\section{Materials and Methods}

The project was approved by the local ethics committee (project no: 325). Patients diagnosed with PS between January 2014 and January 2017 were evaluated. Age, gender, weight, height, body mass index (BMI), occupation and sitting or standing position during working, family history of PS, skin color and hair color were analyzed retrospectively. The BMI of the patients was categorized as $\leq 20.0 \mathrm{~kg} / \mathrm{m}^{2}, 20.1-25.0 \mathrm{~kg} / \mathrm{m}^{2}, 25.1-30.0 \mathrm{~kg} / \mathrm{m}^{2}, 30.1-35.0$ $\mathrm{kg} / \mathrm{m}^{2}$ and $35.1-40.0 \mathrm{~kg} / \mathrm{m}^{2}$. The patients with missing data, acute PS and younger than 18 years old were excluded from the study.

\section{Statistical Analysis}

The data analysis was performed using SPSS for Windows, version 22. The normality of the distribution of continuous variables was determined by Kolmogorov-Smirnov test and histogram. The data were reported as mean \pm standard deviation, or median and range, where applicable. The categorical data were analyzed using chi-square test when appropriate. A p value less than 0.05 was considered statistically significant.

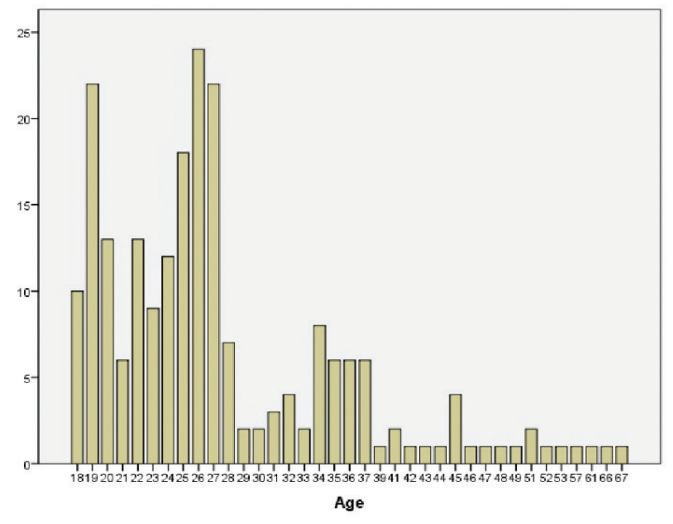

Figure 1. Age distribution of patients with pilonidal disease

\section{Results}

The total number of patients with PS was 217. The patients were between the ages of 18-67 (median: 26 years) (Figure 1 ). The male to female ratio was 5.6. Female subjects were older at the time of diagnosis. The median ages for female and male patients were 27 and 24 years, respectively, but the age distribution was not statistically significant between two genders ( $\mathrm{p}=0.398$ ). The disease had two age peaks at 19 and 24-27 years. (Figure 1 ).

The BMI distribution among patients was seen in Figure 2. Pilonidal disease was statistically significantly more commonly observed in patients with BMI of $25.1-30.0 \mathrm{~kg} /$ $\mathrm{m}^{2}(\mathrm{p}<0.001)$.

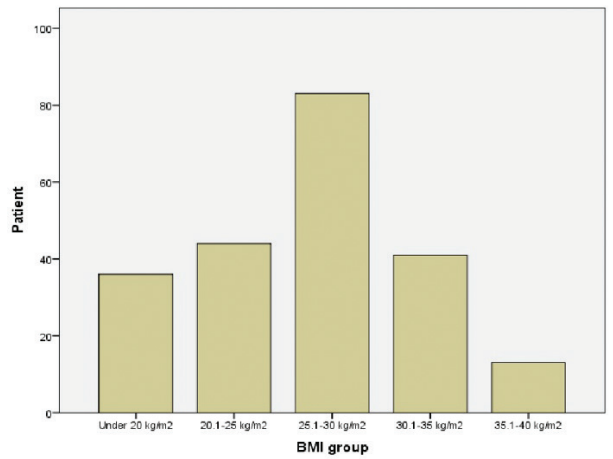

Figure 2. Body mass index distribution of patients with pilonidal disease

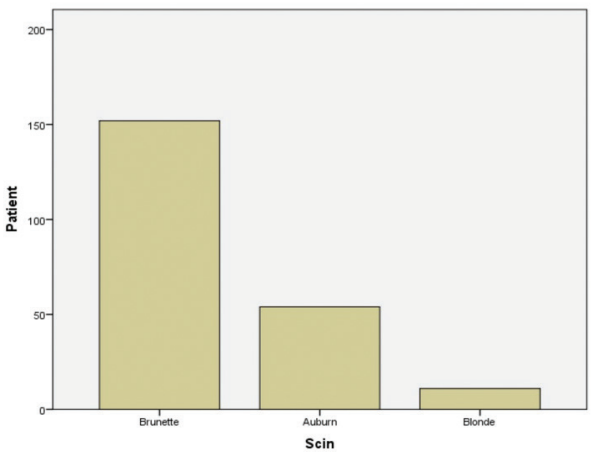

Figure 3. Skin and hair color distribution of patients

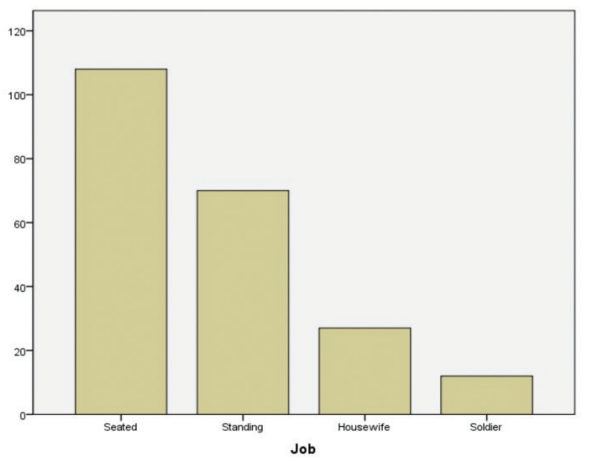

Figure 4. The distribution of occupations and working positions 
The color of the skin and hair was also an important factor (Figure 3). The disease was significantly higher in brunette patients compared to auburn and blonde patients $(\mathrm{p}<0.001)$. The most important variable affecting the disease was the sitting position (Figure 4). The disease was observed in $49.8 \%$ patients with seated positional occupations $(\mathrm{p}<0.001)$.There were no correlation between family history and occurrence of the disease $(\mathrm{p}=0.662)$.

\section{Discussion}

The etiology of PS is a problematic issue in medicine. ${ }^{5}$ Most of the patients (70\%) reported in the literature were between 20 and 30 years of age. ${ }^{6}$ In our study, the mean age of patients was 26 years. More secretion in pilosebaceous glands due to sex hormones in young population may trigger the disease. In our study, the male to female ratio was 5.6 as in previous studies ${ }^{7}$, which means that the disease occurs more frequently in men.

High BMI is an important factor for the occurrence of PS. ${ }^{8}$ In this study, PS was statistically significantly more commonly observed in patients with BMI of $25.1-30.0 \mathrm{~kg} / \mathrm{m}^{2}$ as in the study of Bolandparvaz et al., ${ }^{7}$ referring that overweight patients (BMI >25) were at greater risk of disease. Deep and moist natal cleft in overweight or obese patients is more susceptible to injury with hair ends due to vacuum effect of the area. ${ }^{9}$

In the literature, the skin and hair colors are not wellevaluated variables. In our study, we found that brunette patients had the disease more than auburn and blonde patients significantly. From the point of view, this variable should be evaluated prospectively assessed in other studies. The relationship between occupation and PS has been notified. In one report, Kaymakcioglu et al., ${ }^{6}$ emphasized the importance of sitting position while working, as in our study.

\section{Conclusion}

In conclusion, age, skin color and hair color are unmodifiable risk factors, but prevention of obesity, reducing sitting time and changing routines while fulfilling occupations seem preventive methods.

\section{Ethics}

Ethics Committee Approval: The study was approved by the Adana City Training and Research Hospital Clinical Research Ethics Committee (approval number: 325).

Informed Consent: Retrospective study.

Peer-review: Externally peer-reviewed.

\section{Authorship Contributions}

Surgical and Medical Practices: A.K., S.C., Concept: A.P., A.K., Design: A.K., Data Collection or Processing: S.C., Analysis or Interpretation: A.K., Literature Search: A.P., Writing: A.K., A.P.

Conflict of Interest: No conflict of interest was declared by the authors.

Financial Disclosure: The authors declared that this study received no financial support.

\section{References}

1. Arda IS, Guney LH, Sevmis S, Hicsonmez A. High body mass index as a possible risk factor for pilonidal sinus disease in adolescents. World J Surg 2005;29:469-471

2. Humphries AE, Duncan JE. Evaluation and management of pilonidal disease. Surg Clin North Am 2010;90:113-124.

3. Akinci OF, Bozer M, Uzunkoy A, Duzgun SA, Coskun A. Incidence and aetiological factors in pilonidal sinus among Turkish soldiers. Eur J Surg 1999; 165:339-342.

4. Søndenaa K, Andersen E, Nesvik I, Søreide JA. Patient characteristics and symptoms in chronic pilonidal sinus disease. Int J Colorectal Dis 1995; 10:39-42.

5. Doll D, Friederichs J, Dettmann H, Boulesteix AL, Duesel W. Time and rate of sinus formation in pilonidal sinus disease. Int J Colorectal Dis 2008; 23:359-364

6. Kaymakcioglu N, Yagci G, Simsek A, Unlu A, Tekin DF, Cetiner S, et al. Treatment of pilonidal sinus by phenol application and factors affecting the recurrence. Tech Coloproctol 2005;9:21-24.

7. Bolandparvaz S, Moghadam Dizaj P, Salahi R, Paydar S, Bananzadeh M, Abbasi HR, et al. Evaluation of the risk factors of pilonidal sinus: a single center experience. Turk J Gastroenterol 2012;23:535-537.

8. Harlak A, Mentes O, Kilic S, Coskun K, Duman K, Yilmaz F. Sacrococcygeal pilonidal disease: analysis of previously proposed risk factors. Clinics (Sao Paulo) 2010;65:125-131.

9. Allen-Mersh TG. Pilonidal sinus: finding the right track for treatment. Br J Surg 1990;77:123-132. 